\title{
The Homeowner Flood Insurance Affordability Act: Why the Federal Government Should Not Be in the Insurance Business
}

\author{
Alan D. Eastman \\ Indiana University of Pennsylvania
}

\begin{abstract}
The Biggert-Waters Flood Insurance Reform Act of 2012 revised the National Flood Insurance Program (NFIP) in order to make the debt-ridden program financially viable. Less than two years later the Homeowner Flood Insurance Affordability Act delayed or eliminated many of the Biggert-Waters' reforms, most notably the reduction or elimination of flood insurance subsidies. This legislative activity sparked critical discussions on ways to improve the NFIP in an era of rising sea levels, continuing coastal development, and increasing national debt. Most commentary focuses on the changes in rules and regulations, while missing the salient point relating to the Congressional legislative process itself. If the goals of the NFIP are to be met, sound policies have to not only be enacted, but also implemented and sustained. Flood insurance, mitigation of risk, and disaster relief are intertwined and, although well intentioned, sometimes at cross-purposes. Financial viability requires economic discipline imposed by a capitalist marketplace, whereas the recent policy reversal relating to the NFIP highlights why the Federal Government should not be in the insurance business.

Key Words: Flood insurance, subsidies, legislation, mitigation of risk
\end{abstract}

\section{Introduction}

The National Flood Insurance Program (NFIP) was created in 1968 by the National Flood Insurance Act $^{1}$ in response to a lack of available flood insurance in the private market. In addition to insurance, the NFIP is involved with risk identification and assessment, and risk mitigation. The NFIP aims to promote floodplain management by promoting community involvement in appropriate land use and building requirements and by encouraging households to engage in mitigation efforts and to insure against flood loss. ${ }^{2}$ The NFIP is supposed to be self-sustaining, but major disasters in the last ten years, including Hurricane Katrina and Super Storm Sandy, have exposed the inadequacies of the program's subsidized flood insurance premiums in relation to increasing risk exposure. The NFIP is approximately $\$ 25$ billion in debt to the U.S. Treasury, with additional claims from Hurricane Sandy likely to push the debt closer to $\$ 30$ billion.

The financial viability of the NFIP is not likely to improve without dramatic changes in the program. At the end of 2012, 5.5 million NFIP policies provided approximately $\$ 1.3$ trillion of coverage (Kousky and Kunreuther, 2013). NFIP policy premiums total about $\$ 3.5$ billion per year in support of $\$ 527$ billion of coastal flood plain liabilities. ${ }^{3}$ Rising sea levels and more frequent severe weather events caused by climate change 4 along with continuing coastal development (encouraged in part by subsidized flood insurance premiums ${ }^{5}$ ) will only exacerbate the financial problems of the NFIP.

\section{Legislative Action}

In response to these problems, the U.S. Congress overwhelmingly passed the Biggert-Waters Flood Insurance Reform Act $^{6}$ in 2012. Biggert-Waters aimed to put the NFIP on solid financial footing by phasing-out or eliminating premium discounts so that policyholders would pay the true actuarial cost of their insurance protection. In order to determine the true cost more accurately, the legislation required updated risk maps incorporating the best available climate science and risk of rising sea levels. These changes would result in large premium increases for many policyholders. ${ }^{7}$

Corresponding author: Alan D. Eastman, Indiana University of Pennsylvania, 322F Eberly College of Business and Information Technology, 644 Pratt Drive, Indiana, PA 15705, Email: aeastman@iup.edu

(C) This article is distributed under the terms of the Creative Commons Attribution License, which permits unrestricted use and redistribution provided that the original author and source are credited.

ISSN 2167-9606 Print/ ISSN 2167-9614 Online | (c) 2015 The Author(s) Published by World Scholars / http://www.worldscholars.org 
Not surprisingly, notices of higher premiums and risk reclassifications resulted in immediate, forceful and sustained opposition to the implementation of Biggert-Waters. Stories of exorbitant rate hikes and individual hardships fueled protests by policyholders and representatives from coastal states. The lending and real estate industries mounted extensive lobbying campaigns. ${ }^{8}$ The result: Congress did an almost complete one hundred and eighty degree turn by passing, again with overwhelming support, the Homeowners Flood Insurance Affordability Act in 2014. ${ }^{9}$ Even Congresswoman Maxine Waters, one of the sponsors of the 2012 reform bill, also sponsored the 2014 reversal legislation, stating that "FEMA, in my estimation, has distorted the intentions of a wellmeaning piece of legislation," and that she was "outraged by the increased costs of flood insurance premiums."10 A non-technical description of the Homeowners Flood Insurance Affordability Act (also called Grimm-Waters) is provided by (Beer, 2015, p.7):

Grimm-Waters scaled back many of the key reforms on Biggert-Waters. Grandfathering - the practice in which a person buying a property with flood insurance could assume the seller's low ratewas restored. The so called "property sales trigger, " which required buyers to pay full risk price at purchase, was repealed. Overall rate increases would be capped at anywhere from 15 to 18 percent per year for an individual property, 25 percent for second homes or businesses. Although a small surcharge would be applied to all policies to help fill the fiscal hole of the NFIP, some policyholders would receive refunds for "overpayment" that occurred during the brief Biggert-Waters regime. An affordability study would be conducted. In sum, it was back to business as usual.

\section{New Proposals}

What should be done now? The NFIP is still in debt and facing future financial uncertainty. Representative Earl Blumenauer, one of the five Democrats in the House who voted against the Homeowners Flood Insurance Affordability Act, said Congress was simply "kicking the can down the road" (Beer, 2015). How can Congress, the insurance industry, homeowners, and taxpayers deal with the competing goals of financial viability and affordable premiums? Can the current federal program be adjusted and fixed, or should it be dismantled and replaced? Two proposals for modifying the NFIP will be discussed: (1) instituting an individual mandate that requires every owner of property in a 100-year flood zone to purchase and maintain flood insurance (Lemann, 2015), or (2) incorporating a means-tested voucher program within the NFIP that is linked to mitigation activities to address the affordability of higher, actuarially sound rates (Kousky and Kunreuther, 2013).

An individual mandate, analogous to the requirement that everyone must purchase health insurance as part of the Affordable Care Act, would require all property owners in flood zones to purchase flood insurance. This system expands mandatory participation beyond mortgaged properties and removes lenders from their position of enforcement officers in the flood insurance program. NFIP would no longer need to offer subsidized rates as incentives for participation in the program, and having a larger pool of policyholders would make the program more financially stable. Providing exemptions to lowincome homeowners, or linking premiums to a percentage of income, could be used to address the affordability issue. Forcing property owners to pay premiums at actuarial rates makes them, and potential future property owners, aware of the true costs associated with the flood risks they face and allows them to decide if the benefits of living in the flood zone outweigh the costs. The cost of floods will be felt exante, perhaps discouraging risky development, whereas now property owners bear the cost of floods mainly after the flooding has already occurred (Lemann, 2015).

Means-tested vouchers could be used in conjunction with true risk-based pricing to address the affordability issue that doomed Biggert-Waters, while at the same time allowing for the necessary increase in premiums for financial viability. Risk-based premiums also provide information to property owners, developers, and communities necessary to evaluate and appreciate the true cost of their decisions. Vouchers (based on household income) may be used not only to reduce premiums, but also to cover the costs of loans used for mitigating damage to residential property. In fact, mitigation would be required for a property owner to be eligible for a voucher. Low-interest loans would be provided to policyholders with the loan being repaid via a reduction in insurance premiums. Vouchers would be linked to the individual owner and their income level, while the loans would be attached to the property itself. In this way, the indebtedness of the low-income owner would not be increased and the mitigation efforts would be taken over by the new owner when the property is sold (Kousky and Kunreuther, 2013). The authors summarize the benefits of their approach as follows: ${ }^{11}$

Everyone benefits from this program. The homeowner has affordable annual payments and a safer home. The NFIP has lowered its exposure through mitigation and has improved its financial soundness 
through pricing that is closer to risk based. The financial institution providing the mortgage to the homeowner has a more secure investment because expected losses from a flood event are reduced. And the general taxpayer benefits from a potentially reduced need for disaster aid or bailouts of the NFIP.

\section{Analysis}

Both of the proposals require reinstatement of the basic provisions of Biggert-Waters in order to get premiums to reflect the true cost of the flood risk associated with living in flood prone areas. This is required not only for financial viability, but also to eliminate the increased demand for property development caused by below market pricing of risk. Mitigation is another important component of both proposals, and indeed, likely the most important factor in dealing with the problem of flood damages in the long run. Environmentalists in particular emphasize the importance of getting people and property out of harm's way, especially if one believes that climate change will contribute to higher sea levels and more powerful storms in the future. Making property owners aware of the risks and making them bear the costs associated with flood risks may result in changes in behavior. Community leaders and developers may decide to focus growth away from floodplains, and property owners may be persuaded to mitigate flood damage by making structural improvements to their properties, or by relocating after a flood occurs, rather than vowing to rebuild and persevere as has seemed noble to some following prior natural disasters.

For property owners to truly bear the cost, however, the federal government must make changes in its disaster relief programs. No longer can property owners be provided financial assistance if the result is simply to rebuild without reducing future risk. Disaster relief funds must be tied to mitigation efforts, such as raising existing structures above expected flood levels, or provided to allow property owners to relocate rather than to rebuild. Relief funds should also be available only for properties covered by flood insurance. As long as people believe that the federal government will provide financial assistance after a disaster with no strings attached, they will not recognize nor expect to bear the full cost of the flood risk.

Will the federal government be able to manage a national flood insurance program capable of determining and updating full-risk premiums on a timely basis? Will the federal government be able to effectively link flood insurance and disaster relief to risk mitigation? Using history as a guide, the following examples indicate that the answer to both questions is, most likely, no.

- The unraveling of the Biggert-Waters reforms so quickly and completely provides evidence that Congress may not be able to make the tough decisions necessary for financial viability, nor can they stay the course in the face of large-scale lobbying efforts. "Biggert-Waters represented a rare moment when fiscal and environmental common sense overlapped just long enough for policymakers to look beyond the horizon of a 30year mortgage. The undoing of these reforms proves that our political system can't even see past the horizon of the next election." 12 A similar example can be found in the implementation of the individual mandate of the Affordable Care Act requiring all individuals to be covered by health insurance or be subject to a fine. A Wall Street Journal report indicates that due to a series of exemptions, almost 90 percent of uninsured Americans won't be subject to the fine in 2016 (Miller, 2014). This statistic may make one pause to consider the effectiveness of an individual mandate for flood insurance as proposed above.

- Repetitive loss properties represent about $1 \%$ of NFIP policies, yet are responsible for approximately $30 \%$ of NFIP's losses. ${ }^{13}$ In private markets, premiums for these properties would have skyrocketed, coverage would have been dropped, or mitigation would have been required as a condition of continued insurance.

- Even non-discounted NFIP premiums are inadequate. Anecdotal evidence suggests that flood maps are outdated and inaccurate. ${ }^{14}$ NFIP flood maps depend on historic data, with no consideration given to risks associated with sea level rise. The impact of catastrophic losses, such as those resulting from Hurricanes Katrina, Rita, and Wilma in 2005, was intentionally minimized in loss calculations to avoid premium increases or the elimination of subsidies (Fox, 2014). Private companies without taxpayer back-up would find it necessary to include the most up-to-date information and modeling techniques in their rate determinations.

- FEMA did not adequately follow up on community mitigation efforts that are supposed to be requirements for participation in the NFIP. In a private market, these communities would have been dropped from the program in a timely manner to prevent excessive losses.

- Analyses of the NFIP after Hurricane Katrina recommended many of the reforms that eventually became part of Biggert-Waters ${ }^{15}$, but the federal government took several years to enact any 
significant changes. (And as we saw earlier, then dismantled the changes less than two years later.) In a private market, companies react more quickly and operate more efficiently, bypassing the massive government bureaucracy.

\section{Conclusions}

The NFIP has been subject to considerable scrutiny since the catastrophic events of 2005, led by Hurricane Katrina, created the need for significant borrowing. Environmentalists, insurance experts, and members of Congress, among others, studied the NFIP and proposed changes to make the program financially viable. Congress passed the Biggert-Waters Flood Insurance Reform Act in 2012 to implement procedures that would increase flood insurance premiums to reflect actual flood risk. These reforms were delayed or repealed by the Homeowners Flood Insurance Affordability Act of 2014. This series of events is indicative of a more fundamental problem relating to the provision of flood insurance - the federal government is not well equipped to be in the insurance business.

Financial viability requires policyholders to pay the full actuarial cost of their flood insurance coverage. This is necessary for sustainability and also to signal to and impose upon property owners the true cost of their decision to locate in a floodplain. Significant effort and resources are required to continually update rates using the best techniques and information available. The government has failed to accomplish these tasks because market discipline is required to manage the risks and rewards effectively. Business risk must be managed without a taxpayerfunded safety net. Difficult underwriting and pricing decisions cannot be ignored or "kicked down the road" in a competitive marketplace. Mixing the government's social welfare agenda, especially when it comes to assisting low-income households, with the requirements for financial viability, have the perverse effect of increasing the overall risk while shifting the financial burden onto taxpayers in general.

The federal government needs to get out of the flood insurance business, making it possible for private insurers to step into the market. Private insurers cannot enter the market in any meaningful way if the government continues to offer subsidized premiums. The government may assist the transition by providing access to government databases containing loss histories and risk assessments, but private companies must be free to develop their own set of maps and rates. The government must develop disaster relief programs that require mitigation and relocation, rather than rebuilding. Property owners must know that they need to protect their own property from the risk of flood and that the government won't bail them out in the end even if the property owner ignores the risk and doesn't purchase flood insurance. The government needs to develop and implement an exit strategy so that NFIP policies can be terminated. Existing policyholders who have been provided with subsidized insurance and have relied upon the existence of the NFIP may suffer during the transition. Property owners may believe they are entitled to subsidies because they have enjoyed them for so long, but they are not. ${ }^{16}$ Lehrer (2008) proposed a combination of land buy-outs and one-time tax credits or grants to compensate homeowners for the decline in the value of their property resulting from the termination of the NFIP. And if private insurance companies are unwilling to insure certain high-risk properties, then perhaps it is time to admit that some past development in floodplains was unwise and needs to be undone, rather than trying to continue a government program to make such properties viable for the owners, paid for by the taxpayers.

Although this quote was made seven years ago, it sums up the situation just as well today. "The National Flood Insurance Program is broken and needs serious change. In the long term, it needs to go.",17

\section{Notes}

1. 44 C.F.R. Section 59.2 (2014).

2. Excellent descriptions of the NFIP may be found in (Abbott, 2014) and (Kousky and Kunreuther, 2013).

3. This information comes from a report by a research analyst at the Center for American Progress. See (Fogarty, 2014).

4. A Federal Emergency Management Agency report predicts that the total number of NFIP policies may double by the year 2100 while the loss cost per policy may increase by 10 to 15 percent through the year 2020, 20 to 60 percent through the year 2080, and by 90 percent by the year 2100 . See (Abbott, 2014).

5. (Fox, 2014) provides evidence of an increase in coastal development after the creation of the NFIP in the late 1960s. "And until the 1970s, landowners were reluctant to build on the coasts because of the high risk of hurricanes and storm-driven floods. The latter part of the twentieth century, however, saw a significant shift. From 1970 to 2010, population in the coastal water-shed counties of the United States increased by 45 percent, or 50.9 million people."

6. Biggert-Waters Flood Insurance Reform Act of 2012, Pub. L. No. 112-141, 126 Stat. 405, 916 (2012).

7. (Fox, 2014, p.8) provides an excellent description of the major provisions of Biggert-Waters, including the following: (1) FEMA must update and maintain risk maps for all populated areas and areas of possible population growth; (2) The practice of grandfathering, whereby homeowners could keep their old premiums even when a revised risk map reclassified them into a higher risk zone, will be phased out; (3) FEMA's cal- 
culation of average losses used to calculate premium levels must include catastrophic loss years; (4) The annual limit on premium increases is increased from 10 percent to 20 percent ( 20 to 25 percent for second residences and other special categories of homes); (5) Mandated annual increases in premium rates until the premium reflect full risk rates; and (6) The immediate increase to full-risk rates for currently uninsured properties, properties with a lapsed NFIP policy, and properties purchased after the date of enactment of BiggertWaters.

8. National Association of Realtors president Steve Brown congratulated Realtors for flooding Congress with 300,000 letters and more than 11,000 phone calls protesting the rate hikes from Biggert-Waters provisions, while American Bankers Association president Frank Keating said the passage of the Home Flood Insurance Affordability Act, reversing and delaying many of the Biggert-Waters provisions, put an end to the "unintended consequences" of Biggert-Waters (Fogarty, 2014).

9. Civic Impulse. (2015). H.R. 3370 - 113th Congress: Homeowner Flood Insurance Affordability Act of 2014. Retrieved from https://www. govtrack.us /congress/bills/113/hr3370

10. (Beer, 2015, p.7)

11. Kousky and Kunreuther, 2013, p. 18.

12. Beer, 2014, p. 8.

13. Lemann, p. 8. Repetitive loss properties have had two or more flood insurance claims of $\$ 10,000$ or more in ten years.

14. For example, Sallie Clark, first vice president of the National Association of Counties, stated "We weren't opposed to reform...We wanted FEMA's flood maps to be accurate." The maps, she said, were badly outdated (Beer, 2014, p.6). And in a study of the impact of Biggert-Waters on flood insurance premiums in New Jersey and New York, it was noted that FEMA had been in the process of updating its flood maps prior to Sandy because the previous maps had not been revised in more than 25 years (Kousky and Kunreuther, 2013, pp. $8-9$.

15. For example, see (Lehrer, 2008).

16. (Fox, 2014, p. 14) examines legal doctrines that could possibly support claims of an entitlement to subsidized flood insurance and concludes that although the backlash against the elimination of subsidized rates for flood insurance established briefly by Biggert-Waters was to be expected, "the receipt of subsidies in the past does not create an entitlement to any particular lifestyle in the future."

17. Lehrer, 2008, p. 1)

\section{References}

Abbott, E. (2014). Flood Insurance and Climate Change: Rising Sea Levels Challenge the NFIP. Fordham Environmental Law Review, Symposium 2014, 26 Fordham Envtl. Law Rev. 10.

Beer, B. (2015). UNDERWATER. Earth Island Journal, Winter 2015, Vol. 29, Issue 4, p. 36-43.

Ben-Shahar, O. (2014). Washington Is Encouraging The Next Hurricane Sandy, By Creating New Subsidies For Flood Insurance. Forbes Opinion 3/25/2014. http://www.forbes.com/sites/realspin/2014/03/25/wash ington-is-encouraging-the-next -hurricane-sandy -bycreating-new-subsidies-for-flood-insurance [accessed on Feb. 3, 2015].

Biggert-Waters Flood Insurance Reform Act of 2012, Pub. L. No. 112-141, 126 Stat. 405, 916 (2012).

Boatwright, J. (2015). Proposal aims to ease sting of soaring flood insurance rates. Tampa Tribune, Feb. 20.

Civic Impulse. (2015). H.R. 3370 - 113th Congress: Homeowner Flood Insurance Affordability Act of 2014. Retrieved from https://www.govtrack.us/ congress/bills/113/hr3370

Fogarty, M. (2014). Victory on Flood Insurance Will Be Loss, Too. National Mortgage News, April 21, Vol. 38, No. 30, p. 4.

Fox, S. (2014). This is Adaptation: The Elimination of Subsidies Under the National Flood Insurance Program. Columbia Journal of Environmental Law, 39 Colum. J. Envtl. L. 205.

Kousky, C. and H. Kunreuther (2013). Addressing Affordability in the National Flood Insurance Program. Resources for the Future, Issue Brief 13-02.

Lehrer, E. (2008). Reforming the National Flood Insurance Program after 35 Years of Failure. Competitive Enterprise Institute, July 2008, No. 2.

Lemann, A. (2015). Trolling Back The Tide: Toward An Individual Mandate For Flood Insurance. Fordham Environmental Law Review, Winter 2015, 26 Fordham Envtl. Law Rev. 166.

Miller, J. (2014). Obamacare individual mandate isn't so much of a mandate. CBS News. http://www.cbsnews .com/news/obamacare-individual-mandate-isnt-somuch-of-a-mandate/ [accessed on Feb. 24, 2015].

National Flood Insurance Act of 1968. 44 C.F.R. Section 59.2 (2014)

Taxpayers for Common Sense (2014). Washington: Congress Just Undid the 1 Good Thing It's Done on Climate Change. Plus Media Solutions, US Official News, March 19, 2014. 